JELTL (Journal of English Language Teaching and Linguistics) e-ISSN: 2502-6062, p-ISSN: 2503-1848

2019, Vol. 4(1)

www.jeltl.org

\title{
Motivating EFL Learners Comprehensively: Dörnyei's Taxonomy of Classroom Motivational Strategies
}

\author{
Ernita Raharja \\ Graduate School, Yogyakarta State University, Indonesia \\ email: rahardja.nita.2017@student.uny.ac.id \\ Ashadi \\ Graduate School, Yogyakarta State University, Indonesia \\ email: ashadi@uny.ac.id
}

\begin{abstract}
Learning English as a foreign language is considered as a long-term process. During the period of learning, students might undergo 'ups' and 'downs' issue related to motivation swings. It is believed that motivated learners likely to outperform others who have high language aptitude but possess low motivation. For this reason, EFL teachers are required to involve strategies that captivate EFL students' motivation. Motivating students should not only rely on immediate teaching strategies or a single activity since learning English as a foreign language is not an immediate process. Students tend to show fluctuated motivation in a time while in the other occasions could suffer in learning. Hence, how motivation is considered as a process rather than a single state is described. Examining other perspective about motivation and the changing of focus in researching motivation show that seeing motivation as a process indicates more promising results for EFL students' learning accomplishment. Pointing out the importance of motivation in English learning attainment and the need of continuum process in motivating students, this paper offers the practical and comprehensive classroom motivational strategies by applying Dörnyei's motivational taxonomy.
\end{abstract}

Keywords: motivation, motivational strategies, EFL teacher, EFL students

JELTL (Journal of English Language Teaching and Linguistics), 4(1), 2019 


\section{INTRODUCTION}

Abundant teaching techniques and strategies are promoted as attempts in assisting EFL students to learn English. It is because teaching English as second or foreign language is not an easy task for EFL teachers. This situation requires $\mathrm{s}$ a lot of preparations and considerations. Besides on various aspects which are significant to help EFL students' learning, motivation has long been known as one of substantial notions in language teaching and learning. Motivation has been recognized as one of significant factors that contributes to the success of EFL or ESL' students in learning (Cheng \& Dörnyei, 2007). Responding to the fact that motivation is a pivotal aspect that contributes to L2 or foreign language attainment, English instructional process should promote students' motivation to generate and maintain students' enthusiasm. Accordingly, classroom teaching strategies that can captivate students' motivation is fundamentally important to build convenient learning environment.

Considering the significant contribution of motivation, various studies have been proposed English teaching scenarios to trigger students' motivation in learning. Loi, Thi, and Uyen (2016) reports that various teaching strategies which involved reward could develop students' motivation on learning English. The rewards, as a means of extrinsic motivation, were given in the forms of teachers' feedbacks and presents. On the same attempt, Mahdi (2015) proposes a variety of strategies and tactics applied by teachers to motivate their students to talk in EFL classroom. These involved enhancing communication, minimizing negative factors, using games, and other co-curricular activities. Moving to more specific motivational instruments in ELT, Ilter (2009) reveals through a large-scale survey study that the use of technology in EFL classroom attract students' motivation hence, learning a foreign language seemed to be affected by different technological equipment. Considering ELF students' mental state, Phothongsunan (2016) proposes several interactive ways to increase students' motivation in learning English while at the same time he attempted to develop their personal identity. The strategies involved role plays, narratives, projects, and reading tasks.

The proposal of motivational strategies above could be categorized into two group: a selection of classroom activities and learning resources and the way the feedback is given. Indeed, these strategies provide insights for teachers to have more references about teaching strategies that could be implemented in their English instructional process to increase students' level of motivation. However, it should be noted that motivation is one of mental states in which possibilities for students to have ups and down conditions might emerge. Guilloteaux \& Dörnyei ( 2008) assert that motivation is not only a primary stimulus to generate second or foreign language learning but also a strength to maintain long-term process in learning a language. This implies that motivation is a multifaceted construct. Promoting students' motivation should not only rely on immediate teaching strategies or a single activity. When students engage in such an activity, possibly they will show fluctuating motivation in learning at that time. However, when the strategies are withdrawn or are no longer present, students' learning enthusiasm might be low again. Further, EFL teachers should know that learning language takes long-term process. Teacher should also know that students might undergo various influences that make them feel anxious, unmotivated, or stressful during the long journey in learning English. 
Having said that, EFL teachers should bear in mind that motivating students, again, is a long-term process including reshaping students' mindset from one situation to another condition in which their mental states are involved to initiate and maintain their actions (Dörnyei, 2001; Dörnyei, 1998). These conditions affirm that EFL teachers should see motivation in L2 or FL context is a multifaceted construct, hence EFL students' motivation could not be merely seen as a static mental or emotional state (Dörnyei, 1998). Since it is a multifaceted construct, there are abundant factors influencing students' motivation to learn. Although there are various factors contributing to students' motivation in learning, teachers' influences on it are significant (Astuti, 2016).

With regard above conditions, teaching and learning process should involve strategies that also accommodate how to generate and maintain the motivation. In addition, it should be considered that motivational strategies should consider the "ups and downs" of students' motivation because the possibility of motivation swing among students are very possible. Initially, the definition of motivation in general and in the context of language learning is elaborated. After that, the analyses on how motivation has a clear link in ELT is established. It is then followed by a description of another motivation viewpoint emphasizing that seeing motivation as a process would tend to result in better language learning results. Afterwards, the timeline descriptions toward the shift of motivation research area is established. Finally, the main discussions offer a classroom teaching model by applying Dörnyei's motivational teaching strategies (Dörnyei, 2001). To be more specific but not limited to, the plan of the learning scenario proposed in this study in applying Dörnyei's motivational taxonomy takes an example of $12^{\text {th }}$ graders of Vocational High School (VHS afterwards) in Indonesia in which English is considered as a foreign language. The final remarks would provide standpoints of thought for applying for Dörnyei"'s motivational strategies in ELT.

\section{DEFINING MOTIVATION}

Originally, the term motivation is generated from a Latin verb "movere" which mean to move (Dörnyei \& Ushioda, 2011). Motivation deals with something which makes us keep us going, keep us working, and helps us achieve tasks, therefore motivation is a not a product, but it is a process. Since it is considered as process, motivation could not be directly observed but it could be inferred from actions or activities (e.g., choice of tasks, effort, and persistence) and verbalizations (e.g., "I really want to work on this") (Schunk, 2010). These actions or activities involve both physical and mental activity. Physical activity entails effort, persistence, and overt actions (Schunk, 2010). This is also known as strategy or method to achieve the goals (Brophy \& Wentzel, 2014). Meanwhile, Mental activity covers various cognitive actions as planning, rehearsing, organizing, monitoring, making decisions, solving problems, and assessing progress (Schunk, 2010). Hence, motivation entails multiple dimensions covering tangible and intangible manifestations that involve both psychical factors and psychological motives. Therefore, motivation is a multifaceted construct encompassing time dimension as a process.

While motivation is seen as the process, the process itself is seen as the result of general reasons for what people do. The theoretical construct which is applied to generate those general reasons is called motive (e.g., a need for social acceptance, and a need to satisfy a curiosity (Brophy \& Wentzel, 2014). This motive then generates a goal as an impetus and directions toward subsequence actions (Brophy \& Wentzel, 2014; Schunk, D.H., 2010). Accordingly, 


\section{Ernita Raharja \& Ashadi}

motive is seen as state that entails further decision and action to achieve final aim. Once, the action is generated by the existence of motive and directive point, motivation is emerged. Hence, motivation is considered as multi-layered mental state involving motive, goal, and action.

Moving to the more specific context of language learning, Gardner (1985) defines motivation as the combination between effort, desire, and favorable attitude to achieve the goal toward learning the language. In this definition, Gardner also involved both mental and physical activity by which motivation is operated. Meanwhile, motivation in the context of foreign or second language learning also covers inner drive, impulse, emotion, or desire that makes someone do a particular action (Brown, 2000). Accordingly, motivation is a generator of certain accomplishment in learning a language. By no means of motivation, there will no action released. In more comprehensive view, Dörnyei concerns motivation as the direction and magnitude (intensity) concerning human behavior, that is, the choice of a particular action, the persistence with it, and the effort expended on it (Dörnyei, 2001). Accordingly, this definition confirms that motivation is seen as a process in which efforts to sustain the actions are required.

From the definition of motivation above, various points can be drawn. It might be concluded that motivation is the instigated and sustained movement or actions in order to achieve certain goal that has been set before actions are executed. The goal or why people decide to do something is important for it is considered as the starting point that will direct someone to begin action. Further, the physical and mental motivational strategies involving both physical and mental actions during the process of actions are required to maintain or sustain the motivation itself (not only in the beginning), especially for long-term run processes, including a second or a foreign language learning journey.

\section{MOTIVATION IN THE CONTEXT L2 OR FOREIGN LANGUAGE LEARNING}

In the context of language learning, motivation has a clear link with language learning process which means that achieving the attainment in language learning requires the combination of efforts and goals along with preferable attitude toward learning language (Gardner, 1985). Compared with general definition of motivation, Gardner added attitude as one of dimensions underlying motivation to learn language. This implies that having positive feelings toward certain language along with its society could boost learners' motivation to learn it. Hence, language attainment would be more achievable if positive attitude toward the target language is possessed by learners.

Concerning the significance of motivation to learn L2 or foreign language, Dörnyei specified that language learners with sufficient motivation can achieve the mastery in a foreign or second language regardless of their language aptitude or other cognitive characteristics (Dörnyei, 2001). This remarkable notion implies that even learners with extraordinary learning abilities are unlikely to persist long enough to attain the language mastery without sufficient motivation (Harmer, 2001). Thus, motivation is one of the main determinants of second or foreign language learning achievement (Clement, Noels, \& Dörnyei, 1994; Tuan, 2012). Additionally, it is also believed that not only for students' achievement, motivation also plays significant roles in students' performance and attendance (Kurt \& Kurt, 2018). Under such 
circumstances, possessing motivation to learn foreign or second language learning is one of key successes in achieving learning goals.

As one of determinant factors of the successful language learning, the role of EFL teachers are also very crucial (Taghavi \& Aladini, 2018). It is because teachers hold various key roles and authorities in classroom. Teachers also function as emotional amplifiers for students by verbalizations they deliver to the students to energize them (Dörnyei, 2001b). What language teachers utter to students could contribute to sustain students' emotional stability. Additionally, Dörnyei (2001b) also stresses that teachers' dimensions which are precious for students to possess high motivation to learn involve: a) teachers' personal characteristics; b) teacher immediacy; c) active motivational socializing behavior; and d) classroom management. These highlight that almost what teachers do to their students would psychologically affects students' level of motivation. Consequently, because of complex roles that the teachers have in the classroom, teachers can affect student motivation in many ways (Schunk, 2010).

Possessing multiple roles in classroom allows EFL teachers to be powerful agents in influencing students' level of motivation to learn. Hence, motivating students in this context is defined as teacher's subsequent efforts including tangible and intangible strategies to generate plentiful learning environment, maintain students' willingness to learn, sustain their efforts, and help them evaluate for better learning strategies to perform in the future.

\section{ANOTHER VIEWPOINT OF MOTIVATION: EXTRINSIC VIS INTRINSIC MOTIVATION}

Intrinsic and extrinsic motivation are considerably the most widely and commonly used terms to recognize the origin of students' motivation. However, these common dichotomies may not provide a clear picture of motivation (Wery \& Thomson, 2013). In addition, Schunk (2010) also stressed that both intrinsic and extrinsic motivation are time and context- dependent, that is, they characterize people only in at a given point in time in relation to particular activity. It is, of course, contradictory toward motivation which is seen as a process, rather than a single or immediate state. Hence, it is important to be highlighted that to help students develop their motivation is not enough to understand whether they are externally and internally motivated. Motivating students must involve time dimension because they tend to undergo psychological swings.

The external forces are known as the source of extrinsic motivation while the internal forces are the origin of intrinsic motivation. Accordingly, extrinsic motivation is a drive appealing someone to involve in an activity for some external consequences, such as rewards, that defines the values of accomplishing the task (Brophy \& Wentzel, 2014; Ersöz, 2004). Furthermore, in extrinsic motivation, rewards are administered by other people, or teachers in this context. It could be recognition, praise, and high grades. Any tangible objects such as sweets or presents are also kind of incentives or rewards. In the other hand, the intrinsic motivation is a determination that motivates a person to engage in particular activity because his or her own intention to naturally do so without any external reward (Brophy \& Wentzel, 2014; Ersöz, 2004).

Having about definitions of external and internal motivation, students' motivation is considered as a kind of source-based states. This may inhibit learning in a long-run process, although it seems to be effective at immediate moment (Ersöz, 2004). Once, the source of 


\section{Ernita Raharja \& Ashadi}

motivation is diminished, their intention to learn also would be dramatically vanished. Further, extrinsically motivated students accomplish tasks purely for the sake of acquiring rewards or avoiding some punishment (Wery \& Thomson, 2013). This kind of situation would relatively hinder them to face learning journey and attain language mastery because the motive for learning is absence.

Above definitions highlight notions that intrinsically or externally motivated students are time and context dependent. Time-dependence can be seen in the way that many things that young children find interesting, gradually lose their appeal as they are growing up. In the context-dependent issue, an example could be in the case of joining an English course. Taking this course is intrinsically motivating for A student but extrinsically motivating for B student. Hence, knowing the nature of motivation as a multifaceted construct in which many goals may present would be more comprehensive in getting students motivated rather than simply considering the sources of motivation only from two angles. Seeing motivation as a process requires more effort and commitment during the long process of learning a language.

\section{RESEARCHING MOTIVATION IN SECOND OR FOREIGN LANGUAGE}

Boosting students' motivation has been a prominent issue in learning L2 or foreign language context. Accordingly, Dörnyei and Ushioda (2011) identify stages in studying motivation in second and foreign language. There were three main phases that embody different point of motivation. The first phase, that is, socio-psychological started during 1950-1990. This approach was introduced by Robert Gardner and Wallace Lambert in 1972. During this era, L2 motivation was about the relationship between motivation and orientation (or goal as what Gardner refers) (Gardner, 1985). The orientation, which was then known as integrative orientation, generates the desire or intention to learn either to foster or to hinder intercultural communication with certain community of target language (Clement et al., 1994; Dörnyei, 2003; Dörnyei \& Ushioda, 2011). However, this notion of integrative orientation in learning L2 generated critical debate due to the conceptual definition and its applicability in L2 and foreign language learning over the world. Thus, exploring students' motivation in learning language is not enough to only understand about the notion of integrative orientation.

While socio-psychological approach was seen to be less applicable, in the early 1990s, the cognitive-situated period of L2 motivation was originated by the sense to revitalize and refocus L2 motivation area from previous approach. This period emphasized more attention to motivation in immediate classroom setting which had stronger impact on the overall students' L2 motivation (Dörnyei \& Ushioda, 2011). In short, this approach focused on task motivations which tend to be a state, rather than a dynamic process. Responding to this condition, Dörnyei (2003) offered another view on the notion of motivation as process over time rather than as the state dichotomy in language learning context. Accordingly, the shift from the cognitive-situated perspective led to more explicit concerns with the dynamic character of motivation and its temporal dimension.

The process-oriented approach has been emerged up to the turn of the century. This approach involves time element that considers the ups and down of motivation by capturing the ongoing changes of classroom motivation overtime. When motivation is only examined in relation to particular learners' behavior and classroom processes, students tend to demonstrate 
fluctuating motivation level within a single lesson (Dörnyei, 2003). Hence, the process-oriented theory captures all L2 motivational processes into several temporal segments: pre-actional stage, actional stage, and post-actional stage. Dörnyei and Ottó (1998) divide the process model of L2 motivation into three temporal segments phases. More specifically, this motivation research phase is summarized in Figure 1.

Understanding different phases of researching motivation in second or foreign language leads to the idea that exploring students' motivation develops to be more comprehensive from time to time. From the latest phase, it entails that students' motivation in leaning a target language involves different dimensions that allow researchers to expand their considerations in more expanding students' source of motivation to learn second or foreign language.

Preactional Stage

\begin{tabular}{|l|}
\hline \multicolumn{1}{|c|}{ CHOICE MOTIVATION } \\
Motivational functions: \\
- Setting goals \\
- Forming intentions \\
- Launching action \\
Main motivational influences: \\
- Various goal properties (e.g. goal \\
relevance, specificity and proximity) \\
- palues associated with the learning \\
outcomes itself, as well as with its \\
- Attitudes towards the L2 \\
and its speakers \\
- Expectancy of success and perceived \\
coping potential \\
- Learner beliefs and strategies \\
Environmental support or hindrance
\end{tabular}

Actional Stage

EXECUTIVE MOTIVATION
Motivational functions:
- Generating and carrying out subtasks
- Ongoing appraisal (of one's achievement)
- Action control (self-regulation)
- Quin motivational influences:
-
- puality of the learning experience
potential, self and social image)
- Teachers' and parents' influence
- Classroom reward- and goal structure
(e.g. competitive or cooperative)
- Influence of the learner group
Knowledge and use of self-regulatory
strategies (e.g. goal setting, learning
and self-motivating strategies)

Postactional Stage MOTIVATIONAL RETROSPECTION

Motivational functions:

- Forming causal attributions

- Elaborating standards and strategies

- Dismissing intention \& further planning

Main motivational influences:

Attributional factors (e.g. attributional styles and biases)

- Self-concept beliefs (e.g. self-confidence and self-worth)

- Received feedback, praise, grades

Figure 1 Process model of L2 motivation. From Motivational Strategies in the Language Classroom (p.22), Z. Dornyei, 2001, Cambridge, England: Cambridge University Press.

\section{DÖRNYEI' MOTIVATIONAL STRATEGIES FRAMEWORK}

It is worth noting that all above elaborated approaches have their own strengths and qualities with their context particularity. Those approaches have somewhat different angles in seeing what aspect that might influence student motivation in pedagogical practice. However, this paper is intended to focus on process-oriented model that employs different phases of motivating EFL students. Dörnyei's motivational teaching strategies (MotS) that concern on process-oriented model is developed particularly for educational purposes and has an advantage over the comprehensiveness and clarity framework (Lamb, 2017). Further, Dörnyei's motivational strategies are likely to be more practical for the techniques promotes a goaldirected behavior that make it feasible for EFL teachers to implement it in their language teaching practices. In Dörnyei's process-oriented model, motivation is seen as a dynamic quality which changes over time in response to variety of influences (Bankier \& Wright, 2012). Hence, motivating students is seen as a process rather than a single state that only requires immediate actions. The motivation processes employ how learners and teachers can generate, maintain, and reflect on motivation during the long-run learning processes. 


\section{Ernita Raharja \& Ashadi}

The first phase of Dörnyei's motivational strategies is establishing basic motivational conditions (Dörnyei, 2001a). It is believed that before learners could generate their motivation to learn a foreign or second language, various preconditions should be set before the next strategies are effectively implemented. It deals with initially providing good atmosphere is a classroom environment.

The second stage is generating initial motivation. It deals with establishing learners' readiness and excitement toward what they are going to learn regardless their previous learning enjoyment (Bankier \& Wright, 2012; Dörnyei, 2001a). Hence, the strategies are generally implemented before learners start doing any actions in learning. It covers but is not limited to attempts, such as increasing their success expectancy, making the materials relevant for them, and promoting the instrumental value of English (Dörnyei, 2001a).

The third phase is maintaining and protecting motivation. When the learners start to learn and experience the long-term process in foreign language learning, it is likely that they tend to lose sight of goals that they have set before. Further, different sources of distractions also contribute to distract students' motivation to learn. Hence, motivational maintenance is required to minimize such conditions. Sustaining students' motivation involves but it is not limited to plans such as delivering tasks in motivating ways, helping learning set specific learner goal, promoting teamwork among learner, and boosting learners' self-confidence by letting them experience the success (Dörnyei, 2001a).

The last phase is encouraging positive self-reflection. This take places when the learners are at the end of tasks or learning period. At this stage, learners are expected to have positive reflection toward their learning attainment so that they can have better strategies for the next stage of learning. The teachers' task then is helping learners to see positively no matter what they have achieved during the learning process including seeing the failures positively. Assisting learners to have positive self-evaluation toward their learning comprises but it is not limited to strategies such as increasing learner's satisfaction and providing motivational feedback.

The following is a learning scenario applying some classroom motivational strategies which are taken from Dörnyei's process model of motivating students. This shows that Dörnyei's motivational strategies could be implemented in everyday classroom activities and teachers are very possible to choose certain strategies for particular students with particular context. To be more specific but not limited to, the learning scenario takes an example of Vocational High School students in Indonesia in which English is considered as foreign language.

\section{- Strategy 1: Formulating constructive group norms explicitly}

Vocational High School students are slightly different from students from regular high schools. They are likely to be more dynamic in behavior. Since students' learning characteristics might vary, formulating constructive group of rules during the beginning up to the end of learning process is very crucial (Richard, Dörnyei, \& Kimberly, 1994). Hence, this is very crucial for the teacher and students together formulate constructive group rules during the beginning up to the end of learning process. It is very important because VHS students tend to take English as a secondary matter. Learning subjects in their study programs usually becomes their priority. Dörnyei (2001a) offers the examples of class rules. 
For students

Let's not be late for

class

In small group work

only English can be

used
For the teacher

Tests should be given

after all students

understand about the

materials

Always give feedback on

students' work
For everybody

Let's try to listen each other.

\section{- Strategy 2: Promoting instrumental values}

The second stage of the learning scenario is promoting instrumental value (Dörnyei, 2001a; Dörnyei \& Ushioda, 2011). This strategy is very crucial for VHS students because they are attending the school to enter certain work field. Hence, promoting the benefits of mastering English for their future career would tend to boost their motivation to learn English. Understanding the instrumental values of English allow students to have a realistic learning goal. English will be seen as one of the ways to achieve success in their professional jobs. By adapting Dörnyei's MotS's model, the following scenario can be established. For example, when students are learning a procedural text, the teacher can:

- Provide students with the practical uses of procedural texts related to their study program.

- Restate the role of English in the world-scale by showing that so many tutorials from scholars in their filed are delivered in English.

\section{- Strategy 3: Making teaching materials relevant for the learners}

The next strategy deals with teaching materials. It is believed that relevant teaching materials allow students to experience meaningful learning (Dörnyei \& Ushioda, 2011). Additionally, relevant teaching materials allow students to adjust their own paces of learning (Bankier \& Wright, 2012). The strategy is also relatively suitable for VHS students. Vocational High Schools deals a lot with a particularity of the context based on their study programs. Every study program requires distinctive competences. Hence, providing English learning materials which are relevant to their study program would generally provide them meaningful knowledge. Still taking learning a procedure text as the example, the teacher can:

- Provide students with procedure texts that they can meet in their study program. For students of Computer and Networking study program, procedure text such as how to promote and sell goods with e-commerce how to install LAN (Local Area Network), and how to install web server would be very useful.

- Always relate the procedure texts to students' interest within their study program. It is very possible that students have different topics interests within the umbrella of the same study program. Hence, it is suggested that the teacher offers different topics for students.

\section{- Strategy 4: Creating learner autonomy}

As suggested by Dörnyei, creating learn autonomy contributes to students' sustainable motivation in learning (Alshehri, 2012; Z Dörnyei, 2001a; Zoltán Dörnyei \& Ushioda, 2011) 


\section{Ernita Raharja \& Ashadi}

Despite teachers are suggested to relate learning process to students' study program as much as possible, they also need to promote students' autonomy in accomplishing tasks. Hence, the teacher may:

- Allow students choose aspects of the learning process. For example, students are given chances to choose their own preferred topics of texts.

- Encourage project work. This would let them organize themselves and provide them chance to produce and connect English and their study program.

\section{- Strategy 5: Increasing learner satisfaction}

Once students satisfy with their learning, they are likely to increase their future performance so that positive learning experience is emerged (Dörnyei, 2001a). Accordingly, positive learning experience might highly contribute to motivate and stimulate learning willingness to pursue knowledge (Abdullah, Ghafri, \& Yahyai, 2019). Under this situation, the teacher may give a private feedback of their learning progress on their written or any of their works. Allowing them to produce a work to use English that relates with their expertise also encourage satisfaction. For example, the teacher can allow VHS students majoring multimedia study program to make a visual product after learning a procedure text (e.g., virtual poster, VLOG, storyboard, etc.). Making their product as visual work would allow them to share and attract wide range of audiences.

Again, abovementioned teaching strategies are likely feasible to be implemented to VHS students. In the same attempt, Bankier and Wright (2012) also propose the similar adaptation from Dörnyei' MotS framework in which the proposal takes college students in Japan as target audiences. This implies that MotS is applicable for different students' English level as well as different learning characteristics.

\section{CONCLUSIONS}

This paper proposes a scenario or EFL instructional strategies which are infused from Dörnyei' motivational teaching strategies (MotS). The comprehensiveness of MotS ensures that motivating EFL students is believed to have significant contribution for students' language learning accomplishment. Importantly, not every strategy and sub-strategy are applicable in every teaching and learning context (Dörnyei, 2001a). Hence, it is strongly suggested for teachers to carefully choose strategy based on several considerations including learners' characteristics, learning styles, and language proficiency level

To condense, it is very possible that everyday classroom activities can be tailored to promote students' motivation trough several motivational teaching stages and activities It is also worth to note that teachers play important role in motivating students because they are key figures or authorities who affect the motivational learning processes by providing mentoring, guidance, support, and limit setting. Motivating students is multifaceted and complex thus it is a long-term process rather than a static mental or emotional state or a goal. 


\section{REFERENCES}

Abdullah, M. Y., Ghafri, H. M. H. Al, \& Yahyai, K. S. H. Al. (2019). A Qualitative Study on the Best Motivational Teaching Strategies in the Context of Oman: Perspectives of EFL Teachers. English Language Teaching, 12(3), 57. https://doi.org/10.5539/elt.v12n3p57

Alshehri, E. (2012). Saudi EFL Teachers' and Students' Perception of Motivational Strategies. Postgraduate Conference in Linguistics \& Language Teaching, 26-54.

Astuti, S. P. (2016). Exploring Motivational Strategies. TEFLIN Journal, 27(1), 1-22.

Bankier, J., \& Wright, A. (2012). Strategies, 43-52. Applying Dörnyei's motivational strategies. In A. Stewart \& N. Sonda (Eds.), JALT2011 Conference Proceedings. Tokyo: JALT.

Brophy, J.E. \& Wentzel, R. . (2014). Motivating student to learn. Motivating student to learn (4th ed.). New York: Routledge.

Brown, H. D. (2000). Teaching By Principles. Teaching by principles: An interactive approach to language pedagogy.

Cheng, H.F., \& Dörnyei, Z. (2007). The use of motivational strategies in language instruction: The case of EFL teaching in Taiwan. Innovation in Language Learning and Teaching, 1(1), 153-174. https://doi.org/10.2167/illt048.0

Clement, R., Noels, K. A., \& Dörnyei, Z. (1994). Motivation, Self-Confidence, and Group Cohesion in the Foreign Language Classroom. Language Learning, 44(3).

Dörnyei, Z. (1998). Motivation in second and foreign language learning. Language Teaching, 31(3), 117-135. https://doi.org/10.1017/S026144480001315X

Dörnyei, Z. (2001a). Motivational strategies in the language classroom. New York: Cambridge University Pres.

Dörnyei, Z. (2001b). Teaching and researching motivation. England: Pearson Education Limited.

Dörnyei, Z. (2003). Attitudes, Orientations, and Motivations in Language Learning: Advances in Theory, Research, and Applications. Language Learning, 53(S1), 3-32. https://doi.org/10.1111/1467-9922.53222

Dörnyei, Z., \& Ottó, I. (1998). Motivation in action: A process model of L2 motivation. Working Papers in Applied Linguistics.

Dörnyei, Z., \& Ushioda, E. (2011). Teaching and Researching Motivation Zoltán Dörnyei and Ema Ushioda Second Edition. Pearson Education Inc.

Ersöz, A. (2004). Intrinsic Motivation in English Language Teaching İngilizce Öğretiminde İçsel Güdülenme, 29(132), 67-71.

Gardner, R. C. (1985). Social psychology and second language learning. London: Edward Arnold.

Ilter, B.G (2009). Effect of technology on motivation in EFL classrooms. Turkish Online Journal of Distance Education, 10(4), 136-158. https://doi.org/10.17718/TOJDE.37730

Guilloteaux, \& Dörnyei, Z. (2008). Motivating Language Learners: A Classroom-Oriented Investigation of the Effects of Motivational Strategies on Student Motivation. TESOL Quarterly, 42(1), 55-77. https://doi.org/10.1002/j.1545-7249.2008.tb00207.x

Harmer, J. (2001). The practice of english language teaching. London: Pearson Education Limited.

Kurt, P. Y., \& Kurt, H. (2018). Instructional Practices that Motivate Students to Learn English. Journal of Education and Future, 31324(14), 119-130. https://doi.org/10.30786/jef.408616 


\section{Ernita Raharja \& Ashadi}

Lamb, M. (2017). The motivational dimension of language teaching. Language Teaching, 50(03), 301-346. https://doi.org/10.1017/s0261444817000088

Loi, D. P., Thi, N., \& Uyen, L. (2016). Motivating EFL Classroom Participation by Rewarding at a Language Center in Ho Chi Minh City, Vietnam. Journal of Applied Linguistics and Language Research, 3(5), 177-189.

Mahdi, D. A. (2015). Motivating Reluctant EFL Students to Talk in Class: Strategies and Tactics. Theory and Practice in Language Studies, 5(8), 1703. https://doi.org/10.17507/tpls.0508.22

Phothongsunan, S. (2016). EFL Motivation through Vision: Role-plays, Narratives, Projects and Reading Tasks. Theory and Practice in Language Studies, 6(5), 919. https://doi.org/10.17507/tpls.0605.02

Richard, C., Zoltan, D., \& Kimberly, A. N. (1994). Motivation, Self-Confidence, and Group Cohesion in the Foreign Language Classroom. Language Learning, 44(3), 417-448.

Schunk, D.H., et al. (2010). Motivation in education: Theory, research, and application. USA: Pearson Education Limited.

Taghavi, F., \& Aladini, F. (2018). The Effect of Modified vs. Authentic Input on Iranian EFL Learners' Reading Comprehension. Theory and Practice in Language Studies, 8(4), 450. https://doi.org/10.17507/tpls.0804.13

Tuan, L. T. (2012). An Empirical Research into EFL Learners' Motivation. Theory and Practice in Language Studies, 2(3), 430-439. https://doi.org/10.4304/tpls.2.3.430-439

Wery, J., \& Thomson, M. (2013). Motivational strategies to enhance effective learning in teaching struggling students. British Journal of Learning Support, 28(3), 103-108. https://doi.org/10.1111/1467-9604.12027 